\title{
Emperical Association of the Relationship between Parental and Child Dental Anxiety-A Structured Review
}

Hemalatha $\mathrm{R}^{*}$, Nirmala S, Vishwaja

Department of Pediatric and Preventive Dentistry, Biochemistry and General Pathology, SRM Dental College, Chennai, Tamilnadu, India

DOI: $10.36347 /$ sjds.2020.v07i02.003

| Received: 03.02.2020 | Accepted: 10.02.2020 | Published: 29.02.2020

*Corresponding author: Hemalatha $\mathrm{R}$

\section{Abstract}

The relationship between parental and child dental anxiety is explicit and has been a controversy which has been studied over many decades. Though various methodologies have been evolved and proposed through the years, it still seems to be a topic of concern. Aim: To provide an overall view of the published link between the explicit relationship between parental and child dental anxiety. Study design: A structured review. Results: Forty three studies were included in the review, which ranged widely between research designs, age ranges and methodologies. The relationship is more evident in children below 8 years. Conclusion: The narrative synthesis demonstrates a significant relationship between parental and child dental anxiety with more evidence in the younger age group.

Keywords: Parental, child, dental anxiety, methodologies.

Copyright @ 2020: This is an open-access article distributed under the terms of the Creative Commons Attribution license which permits unrestricted use, distribution, and reproduction in any medium for non-commercial use (NonCommercial, or CC-BY-NC) provided the original author and source are credited.

\section{INTRODUCTION}

Poor dental health can have deleterious effects on the child's development with regards to psychological, social, emotional and functional aspects. This can have ill effects on overall quality of life. The prevalence of dental anxiety is 6-15\% globally. Dentally anxious children pose a great challenge to the Pediatric dentist which paved the way to investigate the perils of this relationship.

To date, the research literature provides conflicting evidence about parents' effect on their child's dental anxiety status .Some of the evidences clearly indicate that anxious parents struggle to develop a positive dental attitude for their children. Other evidences indicate that parental attitudes have no significant effect on their children's anxiety status .Various reasons have been advocated for these inconsistencies. Anxiety is a complex phenomenon due to the influx of various factors at the cognitive and behavioral levels.

The aim of this study is to provide an overall overview of the available evidence -based attitudes and opinions (in) this aspect.

\section{METHODOLOGY}

A series of different literature searches were performed to obtain a classical view on dental anxiety perspectives between parents and children .The literature search followed a structured pattern of search. The search was limited to publications in the English language alone. The following databases were searched namely OVID, CINAHL, EMBASE, MEDLINE, PsycINFO and Cochrane/DARE EBM. The search revealed 977 publications, the abstracts of which were searched by three author's .Out of these fifty articles met the inclusion criteria. The full text versions of these fifty articles were screened, retrieved and studied for relevance. Checking the reference list revealed another 26 relevant articles which totaled up to 76 from which 43 was short listed articles to assess the relationship between children and parents with relation to dental anxiety.

\section{RESULTS}

\section{Study pool characteristics}

Of the 43 articles reviewed 27 were reviews, 3 were RCT, s, 3 were Meta-analysis, 5 were Research articles, 1 was a clinical study and the rest 4 articles did not mention the study design.

\section{Participant characteristics}

The age ranges varied between 2-19 years. Among the 43 studies some studies used different age ranges, whereas in some studies the age ranges were not revealed. 


\section{Assessment measures used}

Of the 43 studies reviewed some used selfstyled tools and some used established measures.

\section{Evidence on the link between parental and child dental anxiety}

Forty three studies were identified, which reported the link between parental and child dental anxiety status. Across all 43 studies some used selfreport measures using existing scales differentiating the studies according to the quality and types of measures used revealed a heterogenous picture. The strength of association between parental and child dental anxiety measures used appears to be affected by the assessment methods used.

\section{Emperical evidences for age ranges}

Most of the studies included the Pediatric age group, while some studies used the adult population. Various rating scales have been used for assessment namely MCDAS, Corah Corah, s DAS, VPT, CFSSDS, FIS.

\section{Emperical evidence by way of context}

The review revealed varying degrees of associations between parental and child dental anxiety depending on the content of dental visit and the types of measures used .Studies using surveys reported a significant relationship between parents and children with regards to dental anxiety, whereas in the dental clinics it showed more ambivalent results. A small percentage of the studies did not show a significant association between children and parents on dental anxiety.

\section{Evidences with regards to reasons for dental visits}

The survey group revealed a significant association with regards to reasons for dental visit, whereas other studies did not show a significant association.

\section{DISCUSSION}

Dental anxiety has the potential to play an important and significant role in the child's future dental and general health as well as the child's overall emotional and social wellbeing. In this context, considerable effort has been invested in understanding the etiology, development and treatment of children with dental anxiety. As a part of these study progress parental inputs has also studied as it has aroused the interests of clinicians and researchers globally.

The 43 studies included in this review have reported a range of outcomes regarding the outcomes. A certain proportion revealed a significant association between parental and child dental anxiety forums. This is still questionable when considering studies with selfreport measures. Moreover this is further evident in studies using existing scales .Studies which have used parents as proxy for young children is another area of great concern.

The fact that different types of studies using different types of measures are still a controversy which raises methodological concerns. This is coupled with studies using validity measures both internal and external, would raise a validity issue. Similar is the case with studies using reliability issues with regards to both test -retest reliability and reproducibility which is again an area of concern. The same may apply to behavioral and observational measures also. Another approach would be exploring the trends between behavioral and observational measures of dental anxiety. Similar trend can be conceptualized by identifying the constructs.

\section{CONCLUSION}

Concerns such as the above mentioned reveal the need for further research into the custom made methodologies and measurements of dental anxiety status among parents and children on further grounds, though the present survey reveals a significant association.

\section{LIMITATIONS}

Emphasis has to be laid on the use of state of art management scales and validity measures as outcome parameters.

Table 1: Details of 43 papers identified from the literature review and reasons for exclusion

\begin{tabular}{|c|c|c|c|c|c|c|c|c|}
\hline Author & $\begin{array}{l}\text { Yr } \\
\text { of } \\
\text { pub }\end{array}$ & $\begin{array}{l}\text { Place of } \\
\text { study }\end{array}$ & Study objective & $\begin{array}{l}\text { Study } \\
\text { type }\end{array}$ & $\begin{array}{l}\text { Study } \\
\text { population }\end{array}$ & $\begin{array}{l}\text { Measurement } \\
\text { scales }\end{array}$ & Results & Outcome \\
\hline $\begin{array}{l}\text { Mark } \\
\text { B.Powers } \\
\text { \&Paul } \\
\text { Emmelkamp }\end{array}$ & 2007 & $\begin{array}{l}\text { Netherlands- } \\
\text { Amsterdam }\end{array}$ & $\begin{array}{l}\text { To assess virtual } \\
\text { reality exposure } \\
\text { therapy for anxiety } \\
\text { disorders }\end{array}$ & $\begin{array}{l}\text { Meta- } \\
\text { analysis }\end{array}$ & $\begin{array}{l}397 \\
\text { participants }\end{array}$ & VRET & $\begin{array}{l}\text { There was a trend for } \\
\text { dose related response } \\
\text { with more VRET } \\
\text { sessions }\end{array}$ & $\begin{array}{l}\text { Showed an overall } \\
\text { positive response }\end{array}$ \\
\hline Drahota et al. & 2008 & Portsmouth & $\begin{array}{l}\text { To assess AV - } \\
\text { distraction on pain } \\
\text { and anxiety during } \\
\text { minor surgery }\end{array}$ & RCT & $\mathrm{N}=152$ & $\begin{array}{l}\text { Bedscapes } \\
\text { before and } \\
\text { after LA }\end{array}$ & $\begin{array}{l}\text { Patients with high } \\
\text { anxiety experienced } \\
\text { more pain on injection }\end{array}$ & $\begin{array}{l}\text { Pain on injection } \\
\text { is closely } \\
\text { associated with } \\
\text { pre-op anxiety }\end{array}$ \\
\hline Bruce Peltier & 2009 & California & $\begin{array}{l}\text { To assess method } \\
\text { s to alleviate } \\
\text { dental fear }\end{array}$ & Review & & & $\begin{array}{l}\text { To focus on breathing, } \\
\text { imagery, hypnosis and } \\
\text { operatory language }\end{array}$ & $\begin{array}{l}\text { The method can be } \\
\text { employed in } \\
\text { patients with } \\
\text { cognitive } \\
\text { impairements }\end{array}$ \\
\hline $\begin{array}{l}\text { Alessandra } \\
\text { Gorini and } \\
\text { Giuseppe }\end{array}$ & 2008 & Italy & $\begin{array}{l}\text { To assess VR } \\
\text { exposure in } \\
\text { anxious patients }\end{array}$ & Review & & & $\begin{array}{l}\text { VR allows grading such } \\
\text { that the patient can } \\
\text { move simple to complex }\end{array}$ & $\begin{array}{l}\text { VRET is effective } \\
\text { in anxiety } \\
\text { disorders }\end{array}$ \\
\hline
\end{tabular}


Hemalatha R et al., Sch J Dent Sci, Feb, 2020; 7(2): 40-47

\begin{tabular}{|c|c|c|c|c|c|c|c|}
\hline Riva & & & & & & treatment modalities & \\
\hline $\begin{array}{l}\text { Mark } \\
\text { Slovin\& June } \\
\text { Falagario } \\
\text { Wassermann }\end{array}$ & 2009 & Newyork & $\begin{array}{l}\text { To assess if fearful } \\
\text { dental patients } \\
\text { receive less oral } \\
\text { health care }\end{array}$ & Review & & $\begin{array}{l}\text { Anxious patients miss } \\
\text { dental appointments } \\
\text { thereby do not receive } \\
\text { adequate care }\end{array}$ & $\begin{array}{l}\text { Ways to increase } \\
\text { their comfort } \\
\text { levels needs to be } \\
\text { focused upon }\end{array}$ \\
\hline $\begin{array}{l}\text { Christine et } \\
\text { al }\end{array}$ & 2009 & Canada & $\begin{array}{l}\text { To assess the } \\
\text { various } \\
\text { psychological } \\
\text { strategies to } \\
\text { reduce pain during } \\
\text { immunization }\end{array}$ & Review & & $\begin{array}{l}\text { Breathing exercises } \\
\text { helped such children }\end{array}$ & $\begin{array}{l}\text { Evidence showed } \\
\text { that breathing } \\
\text { exercises along } \\
\text { with other } \\
\text { distraction } \\
\text { technique reduced } \\
\text { distress in children } \\
\text { during } \\
\text { immunizations }\end{array}$ \\
\hline $\begin{array}{l}\text { Michelle } \\
\text { Maria et al }\end{array}$ & 2009 & Brazil & $\begin{array}{l}\text { To assess anxiety } \\
\text { and pain in } \\
\text { children under } 5 \\
\text { years }\end{array}$ & $\begin{array}{l}\text { Cross } \\
\text { sectional } \\
\text { study }\end{array}$ & $\begin{array}{l}\mathrm{N}=2735 \\
\text { children }\end{array}$ & $\begin{array}{l}\text { Prevalence of pain was } \\
9.1 \text { and anxiety was } \\
34.7 \%\end{array}$ & $\begin{array}{l}\text { DA was related to } \\
\text { pain in children } \\
\text { below } 5 \text { yrs. }\end{array}$ \\
\hline $\begin{array}{l}\text { Linzette } \\
\text { Deidre } \text { et al. }\end{array}$ & 2009 & Australia & $\begin{array}{l}\text { To review the } \\
\text { evidence for the } \\
\text { effeectiveness of } \\
\text { VR in conjunction } \\
\text { with } \\
\text { pharmacological } \\
\text { analgesia }\end{array}$ & Review & & $\begin{array}{l}\text { There is equivocal } \\
\text { evidence of the effect of } \\
\text { VR in conjunction with } \\
\text { pharmacological } \\
\text { analgesics to relieve } \\
\text { pain }\end{array}$ & $\begin{array}{l}\text { Further research } \\
\text { on the effects of } \\
\text { VR in reducing } \\
\text { pain needs to be } \\
\text { done }\end{array}$ \\
\hline $\begin{array}{l}\text { Regina } \\
\text { Wender et al. }\end{array}$ & 2009 & USA & $\begin{array}{l}\text { To review the } \\
\text { effect of VR } \\
\text { against the effect } \\
\text { of interactivity of } \\
\text { analgesia }\end{array}$ & Review & & $\begin{array}{l}\text { Compared to the non- } \\
\text { interactive group } \\
\text { participant in the } \\
\text { interactive group } \\
\text { showed more pain } \\
\text { reduction }\end{array}$ & $\begin{array}{l}\text { Interactivity } \\
\text { increased the } \\
\text { analgesic } \\
\text { effectiveness of } \\
\text { VR }\end{array}$ \\
\hline
\end{tabular}

\begin{tabular}{|c|c|c|c|c|c|c|c|}
\hline $\begin{array}{l}\text { Wendy } \\
\text { Landier et al. }\end{array}$ & 2010 & Honolulu & $\begin{array}{l}\text { To review the evidences in } \\
\text { four databases regarding } \\
\text { the effectiveness of } \\
\text { complimentary and } \\
\text { alternative medical } \\
\text { interventions }\end{array}$ & Review & & $\begin{array}{l}\text { Distraction, hypnosis } \\
\text { and imagery were the } \\
3 \text { modalities studied } \\
\text { for mind-body } \\
\text { management of pain } \\
\text { and anxiety }\end{array}$ & $\begin{array}{l}\text { Such self regulatory } \\
\text { skills could help in } \\
\text { overall symptom } \\
\text { management }\end{array}$ \\
\hline $\begin{array}{l}\text { Maryrose } \\
\text { Gerardi } \text { et al. }\end{array}$ & 2010 & USA & $\begin{array}{l}\text { To review evidence on the } \\
\text { application of VR exposure } \\
\text { therapyto the treatment of } \\
\text { specific phobias }\end{array}$ & Review & & $\begin{array}{l}\text { VR exposure should } \\
\text { only be applied by } \\
\text { trained professionals }\end{array}$ & $\begin{array}{l}\text { VR exposure is } \\
\text { effective and efficient } \\
\text { in treatment of patients } \\
\text { with anxiety disorders }\end{array}$ \\
\hline $\begin{array}{l}\text { Emily F Law } \\
\text { et al. }\end{array}$ & 2010 & Baltimore & $\begin{array}{l}\text { To examine if increasing } \\
\text { the demand for central } \\
\text { cognitive processing -VR } \\
\text { involved in a distraction } \\
\text { task would increase } \\
\text { children's pain tolerance in } \\
\text { children experiencing cold } \\
\text { pressor pain }\end{array}$ & & & $\begin{array}{l}\text { Children } \\
\text { demonstrated } \\
\text { significant } \\
\text { improvement in pain } \\
\text { tolerance during } \\
\text { distraction relative to } \\
\text { baseline }\end{array}$ & $\begin{array}{l}\text { The effects of } \\
\text { distraction on } \\
\text { childtren's cold pressor } \\
\text { pain tolerance are } \\
\text { significantly enhanced } \\
\text { when the distraction } \\
\text { task includes greater } \\
\text { demands for central } \\
\text { cognitive processing }\end{array}$ \\
\hline $\begin{array}{l}\text { Van } \\
\text { Krevelen and } \\
\text { Poelman }\end{array}$ & 2010 & Netherlands & $\begin{array}{l}\text { To assess the effects of AR } \\
\text {-Augmented Reality with } \\
\text { various applications }\end{array}$ & Review & & $\begin{array}{l}\text { AR technology has } \\
\text { huge benefits with } \\
\text { immense potential }\end{array}$ & $\begin{array}{l}\text { Collaboration of AR } \\
\text { with other sources can } \\
\text { improve practice } \\
\text { management }\end{array}$ \\
\hline $\begin{array}{l}\text { Katherina } \\
\text { Meyerbroker } \\
\text { \& Paul } \\
\text { Emmelkemp }\end{array}$ & 2010 & Netherlands & $\begin{array}{l}\text { To review the use of } \\
\text { VRET- Virtual Reality } \\
\text { Exposure Therapy in } \\
\text { patients with anxiety } \\
\text { disorders }\end{array}$ & Review & & $\begin{array}{l}\text { VRET can be } \\
\text { augmented using } \\
\text { cognitive enhancers }\end{array}$ & $\begin{array}{l}\text { VRET would not only } \\
\text { focus on outcome but } \\
\text { also on the underlying } \\
\text { process }\end{array}$ \\
\hline $\begin{array}{l}\text { Yuko S. } \\
\text { Schmitt et al. }\end{array}$ & 2011 & Seattle & $\begin{array}{l}\text { To examine the effects of } \\
\text { VR as an adjunctive } \\
\text { analgesic technique for } \\
\text { burn patients }\end{array}$ & RCT & 54 children & $\begin{array}{l}\text { VR is an effective } \\
\text { non pharmocological } \\
\text { adjunctive pain } \\
\text { reduction technique }\end{array}$ & $\begin{array}{l}\text { VR with analgesic } \\
\text { technique is effective } \\
\text { and clinically } \\
\text { meaningful }\end{array}$ \\
\hline $\begin{array}{l}\text { Trevor } \\
\text { Thompson } e t \\
\text { al. }\end{array}$ & 2011 & UK & $\begin{array}{l}\text { To examine if the influence } \\
\text { of dental anxiety sensitivity } \\
\text { on coping effectiveness } \\
\text { differs among genders }\end{array}$ & & $\begin{array}{l}76 \\
\text { participants }\end{array}$ & $\begin{array}{l}\text { In males coping } \\
\text { sensitivity was high } \\
\text { and in females } \\
\text { distraction showed } \\
\text { superior strategy }\end{array}$ & $\begin{array}{l}\text { Both coping sensitivity } \\
\text { and distraction } \\
\text { strategies were } \\
\text { effective. }\end{array}$ \\
\hline $\begin{array}{l}\text { David Opris } \\
\text { et al. }\end{array}$ & 2012 & Romania & $\begin{array}{l}\text { To evaluate the efficacy of } \\
\text { VRET with evidence based } \\
\text { treatments }\end{array}$ & $\begin{array}{l}\text { Meta } \\
\text { analysis }\end{array}$ & & $\begin{array}{l}\text { VRET is better in } \\
\text { combination } \\
\text { therapies }\end{array}$ & $\begin{array}{l}\text { VRET can be } \\
\text { recommended as it has } \\
\text { good stability }\end{array}$ \\
\hline
\end{tabular}




\begin{tabular}{|c|c|c|c|c|c|c|c|}
\hline Albert Rizzo & 2012 & USA & $\begin{array}{l}\text { To review the } \\
\text { rationale of VRET } \\
\text { when applied to } \\
\text { anxiety disorders }\end{array}$ & Review & \multicolumn{2}{|c|}{$\begin{array}{l}\text { VRET is found to be useful } \\
\text { either alone or in combination } \\
\text { with other treatment } \\
\text { modalities }\end{array}$} & $\begin{array}{l}\text { VRET can be used as an } \\
\text { adjunctive with various } \\
\text { other combinations }\end{array}$ \\
\hline $\begin{array}{l}\text { Donna Koller } \\
\text { et al. }\end{array}$ & 2012 & Canada & $\begin{array}{l}\text { To review the use of } \\
\text { distraction } \\
\text { techniques for } \\
\text { children undergoing } \\
\text { various treatment } \\
\text { procedures }\end{array}$ & Review & \multicolumn{2}{|c|}{$\begin{array}{l}\text { Evidence based literature is } \\
\text { evident in relation to the use of } \\
\text { distraction techniques }\end{array}$} & $\begin{array}{l}\text { Recommendations will } \\
\text { include greater attention to } \\
\text { child preferences and } \\
\text { temperament as a means } \\
\text { of optimizing outcomes }\end{array}$ \\
\hline $\begin{array}{l}\text { Jeongwoo Lee } \\
\text { et al. }\end{array}$ & 2012 & $\begin{array}{l}\text { South } \\
\text { Korea }\end{array}$ & $\begin{array}{l}\text { To determine the } \\
\text { effects of cartoon } \\
\text { viewing and playing } \\
\text { with favorite toy } \\
\text { before anesthesia } \\
\text { induction }\end{array}$ & & \multicolumn{2}{|c|}{$\begin{array}{l}\text { The effects of cartoon viewing } \\
\text { and playing with favorite toy } \\
\text { before anesthesia induction } \\
\text { proved to be effective }\end{array}$} & $\begin{array}{l}\text { The method seems to be } \\
\text { inexpensive, easy to } \\
\text { administer and } \\
\text { comprehensive way for } \\
\text { anxiety reduction }\end{array}$ \\
\hline $\begin{array}{l}\text { Brian A. } \\
\text { Primack et al. }\end{array}$ & 2012 & Malaysia & $\begin{array}{l}\text { To assess the role of } \\
\text { video games in } \\
\text { improving health } \\
\text { related outcomes }\end{array}$ & Review & \multicolumn{2}{|c|}{$\begin{array}{l}\text { Evidence based support is } \\
\text { existing for the use of video } \\
\text { games in improving health } \\
\text { related outcomes }\end{array}$} & $\begin{array}{l}\text { Video gaming can be } \\
\text { recommended as an allied } \\
\text { adjunctive }\end{array}$ \\
\hline Orrett E et al. & 2012 & USA & $\begin{array}{l}\text { To assess measures } \\
\text { of anxiety control in } \\
\text { dental patients }\end{array}$ & Review & \multicolumn{2}{|c|}{$\begin{array}{l}\text { Minimal sedation would help } \\
\text { patients to alleviate dental } \\
\text { anxiety }\end{array}$} & $\begin{array}{l}\text { Minimal sedation can help } \\
\text { patients overcome the fear } \\
\text { of anxiety and hence can } \\
\text { be recommended }\end{array}$ \\
\hline $\begin{array}{l}\text { Jose Gutierrez- } \\
\text { Maldonado et } \\
\text { al. }\end{array}$ & 2012 & Barcelona & $\begin{array}{l}\text { To assess if VR can } \\
\text { influence pain } \\
\text { related measures } \\
\text { during cold pressor } \\
\text { experience }\end{array}$ & Review & \multicolumn{2}{|c|}{$\begin{array}{l}\text { VR can be used for coping } \\
\text { with pain }\end{array}$} & $\begin{array}{l}\text { VR helped to reduce pain } \\
\text { by increasing pain } \\
\text { threshold }\end{array}$ \\
\hline Amber Choo & 2012 & Columbia & $\begin{array}{l}\text { To assess the use of } \\
\text { VR gaming design } \\
\text { for reduction of } \\
\text { chronic pain } \\
\text { intensity in clinical } \\
\text { settings }\end{array}$ & Review & \multicolumn{2}{|c|}{$\begin{array}{l}\text { VR can be used in clinical } \\
\text { settings }\end{array}$} & $\begin{array}{l}\text { Pain reduction is evident, } \\
\text { therefore it is } \\
\text { recommended in clinical } \\
\text { settings }\end{array}$ \\
\hline $\begin{array}{l}\text { Imran A } \\
\text { Quddus }\end{array}$ & 2016 & London & $\begin{array}{l}\text { To provide an } \\
\text { overall view of } \\
\text { psychological } \\
\text { detection and } \\
\text { management } \\
\text { techniques } \\
\end{array}$ & Review & \multicolumn{2}{|c|}{$\begin{array}{l}\text { Psychological detection and } \\
\text { management techniques } \\
\text { support the patients' treatment } \\
\text { needs in the long run }\end{array}$} & $\begin{array}{l}\text { Patient management can } \\
\text { be enhanced by employing } \\
\text { the right techniques at the } \\
\text { right time }\end{array}$ \\
\hline Ted Jones et al. & 2016 & USA & Research article & $\begin{array}{l}\text { To assess the impact of } \\
\text { VR application for } \\
\text { chronic pain }\end{array}$ & $\begin{array}{l}\text { Visual } \\
\text { Analog } \\
\text { Scale }\end{array}$ & $\begin{array}{l}\text { VR reduced pain } \\
\text { significantly }\end{array}$ & $\begin{array}{l}\text { VR can be a non-opiod } \\
\text { alternative for chronic } \\
\text { pain }\end{array}$ \\
\hline $\begin{array}{l}\text { Alexandra } \\
\text { Negut } \text { et al. }\end{array}$ & 2016 & Romania & Meta-analysis & $\begin{array}{l}\text { To do a meta analytical } \\
\text { review of VR on } \\
\text { neurophysiological } \\
\text { assessment }\end{array}$ & & $\begin{array}{l}\text { Based on random } \\
\text { effect model, } \\
\text { there was large } \\
\text { effect size in } \\
\text { favour of healthy } \\
\text { controls }\end{array}$ & $\begin{array}{l}\text { VR measures for } \\
\text { neuropsychological } \\
\text { assessment can be } \\
\text { recommended }\end{array}$ \\
\hline $\begin{array}{l}\text { Amal Al } \\
\text { Khotani et al. }\end{array}$ & 2016 & $\begin{array}{l}\text { Saudi } \\
\text { Arabia }\end{array}$ & RCT & $\begin{array}{l}\text { To assess the use of video } \\
\text { taped cartoons using an } \\
\text { eye glass system-I - } \\
\text { theatre as an AV } \\
\text { distraction technique on } \\
\text { behavior and anxiety in } \\
\text { children undergoing } \\
\text { restoration }\end{array}$ & & $\begin{array}{l}\text { AV group showed } \\
\text { reduced scores } \\
\text { with reduction in } \\
\text { pulse rate also in } \\
\text { comparison with } \\
\text { the control group }\end{array}$ & $\begin{array}{l}\text { AV distraction seems to } \\
\text { be a useful tool }\end{array}$ \\
\hline $\begin{array}{l}\text { Kausar Sadia } \\
\text { Fakhruddin } e t \\
\text { al. }\end{array}$ & 2016 & Turkiye & $\begin{array}{l}\text { Randomized cross } \\
\text { over clinical study }\end{array}$ & $\begin{array}{l}\text { To assess the } \\
\text { effectiveness of behavior } \\
\text { modification techniques } \\
\text { in combination with } \\
\text { visual distraction with or } \\
\text { without eye wear using } \\
\text { computerized delivery } \\
\text { system during LA } \\
\text { administration }\end{array}$ & & $\begin{array}{l}\text { The technique } \\
\text { proved to be } \\
\text { useful }\end{array}$ & $\begin{array}{l}\text { Can be recommended as a } \\
\text { routine practice }\end{array}$ \\
\hline $\begin{array}{l}\text { C. Lopez Maite } \\
\text { et al. }\end{array}$ & 2016 & Belgium & Review & $\begin{array}{l}\text { To examine the current } \\
\text { tools and the relevancy of } \\
\text { VR }\end{array}$ & & $\begin{array}{l}\text { VR contributes } \\
\text { irrespective of the } \\
\text { underlying } \\
\text { cognitive } \\
\text { impairements }\end{array}$ & $\begin{array}{l}\text { VR and traditional tests } \\
\text { are complimentary to each } \\
\text { other therefore can be } \\
\text { recommended }\end{array}$ \\
\hline $\begin{array}{l}\text { Joanna Piskorz } \\
\text { et al. }\end{array}$ & 2017 & Poland & Research article & $\begin{array}{l}\text { To assess the } \\
\text { effectiveness of VR in } \\
\text { reducing pain due to } \\
\text { venepuncture }\end{array}$ & & $\begin{array}{l}\text { VR seemed to be } \\
\text { effective in } \\
\text { reducing pain due } \\
\text { to venepuncture }\end{array}$ & $\begin{array}{l}\text { The technique can be } \\
\text { recommended for clinical } \\
\text { practice }\end{array}$ \\
\hline Kausar Sadia & 2017 & Turkiye & Clinical study & To assess the & & AV distraction & AV distraction can be \\
\hline
\end{tabular}


Hemalatha R et al., Sch J Dent Sci, Feb, 2020; 7(2): 40-47

\begin{tabular}{|l|l|l|l|l|l|l|}
\hline $\begin{array}{l}\text { Fakhruddin } \text { et } \\
\text { al. }\end{array}$ & & & & $\begin{array}{l}\text { effectiveness of AV } \\
\text { distraction with } \\
\text { computerized delivery of } \\
\text { anesthesia during stainless } \\
\text { steel crown placement in } \\
\text { children with Down's } \\
\text { syndrome }\end{array}$ & $\begin{array}{l}\text { was effective in } \\
\text { computerized } \\
\text { delivery of } \\
\text { anesthesia during } \\
\text { stainless steel } \\
\text { crown placement } \\
\text { in children with } \\
\text { Down's syndrome }\end{array}$ & $\begin{array}{l}\text { recommended as a routine } \\
\text { in clinical practice }\end{array}$ \\
\hline $\begin{array}{l}\text { Zhen Wang } e t \\
\text { al. }\end{array}$ & 2017 & US & Review & $\begin{array}{l}\text { To evaluate the } \\
\text { effectiveness and safety of } \\
\text { treatments for children } \\
\text { with anxiety disorders } \\
\text { using CBT }\end{array}$ & $\begin{array}{l}\text { CBT is effective } \\
\text { in reducing } \\
\text { anxiety symptoms } \\
\text { and improving } \\
\text { functions }\end{array}$ & $\begin{array}{l}\text { Future research is needed } \\
\text { to evaluate components of } \\
\text { CBT }\end{array}$ \\
\hline Justin Dunn & 2017 & USA & Review & $\begin{array}{l}\text { To assess the } \\
\text { effectiveness of Vitual } \\
\text { and augmented reality in } \\
\text { the treatment of phantom } \\
\text { limb pain }\end{array}$ & $\begin{array}{l}\text { Virtual } \\
\text { augmented reality } \\
\text { proved to be } \\
\text { useful }\end{array}$ \\
\hline
\end{tabular}

\begin{tabular}{|c|c|c|c|c|c|c|c|}
\hline $\begin{array}{l}\text { Cristina } \\
\text { Botella et al. }\end{array}$ & 2017 & Spain & Review. & $\begin{array}{l}\text { To examine the evidence } \\
\text { about VRET's efficacy for } \\
\text { phobias }\end{array}$ & & VRET is a useful tool & $\begin{array}{l}\text { VRET can be } \\
\text { recommended for } \\
\text { treatment of phobias }\end{array}$ \\
\hline $\begin{array}{l}\text { Yoren } \\
\text { Gaffary }\end{array}$ & 2017 & & $\begin{array}{l}\text { Research } \\
\text { article }\end{array}$ & $\begin{array}{l}\text { To examine the } \\
\text { effectiveness of VR and AR } \\
\text { in haptic perception of } \\
\text { stiffness }\end{array}$ & $\begin{array}{l}12 \\
\text { particip } \\
\text { ants }\end{array}$ & $\begin{array}{l}\text { VR and AR exert a } \\
\text { psychological effect }\end{array}$ & $\begin{array}{l}\mathrm{VR} \text { and } \mathrm{AR} \text { can be } \\
\text { recommended as a routine }\end{array}$ \\
\hline $\begin{array}{l}\text { Aminabadi } \\
\text { Naser Asl et } \\
\text { al. }\end{array}$ & 2017 & Iran & Review & $\begin{array}{l}\text { To examine if current } \\
\text { researches appropriately } \\
\text { discriminate dental anxiety }\end{array}$ & & $\begin{array}{l}\text { Out of } 104 \text { papers only } 5 \\
\text { studies used different clinical } \\
\text { measures to discriminate } \\
\text { between fear, phobia and } \\
\text { anxiety }\end{array}$ & $\begin{array}{l}\text { Dicrimination was not } \\
\text { evident between fear, } \\
\text { phobia and anxiety } \\
\text { thereby they could be used } \\
\text { interchangably }\end{array}$ \\
\hline $\begin{array}{l}\text { Hisham } \\
\text { Yehia El } \\
\text { Batawi et al. }\end{array}$ & 2017 & Sharjah & $\begin{array}{l}\text { Research } \\
\text { article }\end{array}$ & $\begin{array}{l}\text { To evaluate the } \\
\text { effectiveness of AV } \\
\text { distraction in behavior } \\
\text { modification during dental } \\
\text { caries assessment and } \\
\text { sealant placement in } \\
\text { children with autism } \\
\text { spectrum disorder }\end{array}$ & $\begin{array}{l}\mathrm{N}=28 \\
\text { childre } \\
\mathrm{n}\end{array}$ & $\begin{array}{l}\text { Av distraction proved to be } \\
\text { effective in behavior } \\
\text { management of children with } \\
\text { autism disorders }\end{array}$ & $\begin{array}{l}\text { AV distraction can be } \\
\text { recommended as an } \\
\text { effective tool }\end{array}$ \\
\hline $\begin{array}{l}\text { Laura D } \\
\text { Seligman } e t \\
\text { al. }\end{array}$ & 2017 & Texas & Review & $\begin{array}{l}\text { To review the literature on } \\
\text { dental anxiety and phobia, } \\
\text { including its prevalence and } \\
\text { sequelae }\end{array}$ & & $\begin{array}{l}\text { A multidisciplinary approach } \\
\text { is needed for dental anxiety } \\
\text { management }\end{array}$ & $\begin{array}{l}\text { The recommendation is to } \\
\text { group, classify and treat } \\
\text { phobias in clinical practice }\end{array}$ \\
\hline $\begin{array}{l}\text { Stefano } \\
\text { Cianette } \text { et al. }\end{array}$ & 2017 & Italy & Review & $\begin{array}{l}\text { To assess the evidence of } \\
\text { pharmacological and non } \\
\text { pharmacological } \\
\text { interventions for the } \\
\text { management of dental fear }\end{array}$ & & $\begin{array}{l}\text { The findings indicate the } \\
\text { potential to inform asnd } \\
\text { influence clinical decision } \\
\text { making and guidance } \\
\text { development }\end{array}$ & $\begin{array}{l}\text { The interventions can be } \\
\text { recommended though } \\
\text { significant heterogenecity } \\
\text { may arise. }\end{array}$ \\
\hline $\begin{array}{l}\text { Michelle } \\
\text { Sophie Keller } \\
\text { et al. }\end{array}$ & 2017 & US & Review & $\begin{array}{l}\text { To assess public perceptions } \\
\text { regarding use of VR in } \\
\text { health care }\end{array}$ & & $\begin{array}{l}\text { VR technology seems to be } \\
\text { useful }\end{array}$ & $\begin{array}{l}\text { VR technology can be } \\
\text { recommended }\end{array}$ \\
\hline $\begin{array}{l}\text { James Spyt et } \\
\text { al. }\end{array}$ & 2016 & & Review & $\begin{array}{l}\text { To assess recent assessment } \\
\text { approaches and } \\
\text { psychological management } \\
\text { in dental practice settings }\end{array}$ & & $\begin{array}{l}\text { Expert opinions are available } \\
\text { for psychological management }\end{array}$ & $\begin{array}{l}\text { Psychological } \\
\text { management can be } \\
\text { recommended }\end{array}$ \\
\hline $\begin{array}{l}\text { Catherine } \\
\text { Glennon et al. }\end{array}$ & 2018 & & $\begin{array}{l}\text { Research } \\
\text { article }\end{array}$ & $\begin{array}{l}\text { To determine the effects of } \\
\text { a virtual reality intervention } \\
\text { on pain and anxiety in } \\
\text { patients undergoing bone } \\
\text { marrow aspiration and } \\
\text { biopsy }\end{array}$ & & $\begin{array}{l}\text { Participants in the } \\
\text { experimental and control } \\
\text { group showed a decrease in } \\
\text { pain and anxiety but those } \\
\text { wore VR goggles did not show } \\
\text { significant pain reduction }\end{array}$ & $\begin{array}{l}\text { VR technology to be } \\
\text { revisited to benefit the } \\
\text { patients, though it is a } \\
\text { non-interventional } \\
\text { alternative to traditional } \\
\text { pharmacological methods }\end{array}$ \\
\hline
\end{tabular}

\section{REFERENCES}

1. Themessl- Huber, M. A. R. K. U. S., Freeman, R., Humphris, G., Macgillivray, S., \& Terzi, N. (2010). Empirical evidence of the relationship between parental and child dental fear: a structured review and meta- analysis. International journal of paediatric dentistry, 20(2), 83-101.

2. Powers, M. B., \& Emmelkamp, P. M. (2008). Virtual reality exposure therapy for anxiety disorders: A meta-analysis. Journal of anxiety disorders, 22(3), 561-569.
3. Peltier, B. (2009). Psychological treatment of fearful and phobic special needs patients. Special Care in Dentistry, 29(1), 51-57.

4. Drahota, A., Galloway, E., Stores, R., Ward, D., Severs, M., \& Dean, T. (2008). Audiovisual distraction as an adjunct to pain and anxiety relief during minor surgery. The Foot, 18(4), 211-219.

5. Gorini, A., Riva, G., Deacon, Gould, Kobak, Riva., \& Riva. (2008). Virtual reality in anxiety disorders: the past and the future. Expert Review of Neurotherapeutics, 8(2), 215-233. 
6. Slovin, M., \& Falagario-Wasserman, J. (2009). Special needs of anxious and phobic dental patients. Dental Clinics of North America, 53(2), 207-219.

7. Chambers, C. T., Taddio, A., Uman, L. S., McMurtry, C. M., \& Team, H. (2009). Psychological interventions for reducing pain and distress during routine childhood immunizations: a systematic review. Clinical therapeutics, 31, S77S103.

8. Michelle, Maria, T. (2009). Oliveira and Viviane Colares. The relationship between dental anxiety and pain in children aged 18-59 months. A study in Recife. Cad Saude Publica, 25(4), 743-50.

9. Morris, L. D., Louw, Q. A., \& Grimmer-Somers, K. (2009). The effectiveness of virtual reality on reducing pain and anxiety in burn injury patients: a systematic review. The Clinical journal of pain, 25(9), 815-826.

10. Wender, R., Hoffman, H. G., Hunner, H. H., Seibel, E. J., Patterson, D. R., \& Sharar, S. R. (2009). Interactivity influences the magnitude of virtual reality analgesia. Journal of cyber therapy and rehabilitation, 2(1), 27.

11. Gerardi, M., Cukor, J., Difede, J., Rizzo, A., \& Rothbaum, B. O. (2010). Virtual reality exposure therapy for post-traumatic stress disorder and other anxiety disorders. Current psychiatry reports, 12(4), 298-305.

12. Landier, W., \& Alice, M. T. (2010). Use of complementary and alternative medical interventions for the management of procedurerelated pain, anxiety, and distress in pediatric oncology: an integrative review. Journal of pediatric nursing, 25(6), 566-579.

13. Law, E. F., Dahlquist, L. M., Sil, S., Weiss, K. E., Herbert, L. J., Wohlheiter, K., \& Horn, S. B. (2010). Videogame distraction using virtual reality technology for children experiencing cold pressor pain: the role of cognitive processing. Journal of pediatric psychology, 36(1), 84-94.

14. Meyerbröker, K., \& Emmelkamp, P. M. (2010). Virtual reality exposure therapy in anxiety disorders: a systematic review of process- andoutcome studies. Depression and anxiety, 27(10), 933-944.

15. Schmitt, Y. S., Hoffman, H. G., Blough, D. K., Patterson, D. R., Jensen, M. P., Soltani, M., \& Sharar, S. R. (2011). A randomized, controlled trial of immersive virtual reality analgesia, during physical therapy for pediatric burns. Burns, 37(1), 61-68.

16. Thompson, T., Keogh, E., \& French, C. C. (2011). Sensory focusing versus distraction and pain: moderating effects of anxiety sensitivity in males and females. The Journal of Pain, 12(8), 849-858.

17. Opriş, D., Pintea, S., García- Palacios, A., Botella, C., Szamosközi, Ş., \& David, D. (2012). Virtual reality exposure therapy in anxiety disorders: a quantitative meta- analysis. Depression and anxiety, 29(2), 85-93.

18. Rizzo, A., John, B., Newman, B., Williams, J., Hartholt, A., Lethin, C., \& Buckwalter, J. G. (2013). Virtual reality as a tool for delivering PTSD exposure therapy and stress resilience training. Military Behavioral Health, 1(1), 52-58.

19. Koller, D., \& Goldman, R. D. (2012). Distraction techniques for children undergoing procedures: a critical review of pediatric research. Journal of pediatric nursing, 27(6), 652-681.

20. Lee, J., Lee, J., Lim, H., Son, J. S., Lee, J. R., Kim, D. C., \& Ko, S. (2012). Cartoon distraction alleviates anxiety in children during induction of anesthesia. Anesthesia \& Analgesia, 115(5), 11681173.

21. Primack, B. A., Carroll, M. V., McNamara, M., Klem, M. L., King, B., Rich, M., ... \& Nayak, S. (2012). Role of video games in improving healthrelated outcomes: a systematic review. American journal of preventive medicine, 42(6), 630-638.

22. Ogle, O. E., \& Hertz, M. B. (2012). Anxiety control in the dental patient. Dental Clinics of North America, 56(1), 1-16.

23. Gutiérrez-Maldonado, J., Gutiérrez-Martínez, O., Loreto-Quijada, D., \& Nieto-Luna, R. (2012). The use of virtual reality for coping with pain with healthy participants. Psicothema, 24(4), 516-522.

24. Choo, A. M. L. (2015). Virtual Reality Game Design for the Reduction of Chronic Pain Intensity in Clinical Settings (Doctoral dissertation, Communication, Art \& Technology:).

25. Ahmed, F., Quddus, I. A., Sharif, M. O., \& Ahmed, K. (2016). Dental anxiety: understanding is the key to effective management. Dental update,43(9), 883-890

26. Jones, T., Moore, T., \& Choo, J. (2016). The impact of virtual reality on chronic pain. PloS one, 11(12).

27. Neguț, A., Matu, S. A., Sava, F. A., \& David, D. (2016). Virtual reality measures in neuropsychological assessment: a meta-analytic review. The Clinical Neuropsychologist,30(2), $165-184$

28. Al-Khotani, A., Bello, L. A. A., \& Christidis, N. (2016). Effects of audiovisual distraction on children's behaviour during dental treatment: a randomized controlled clinical trial. Acta Odontologica Scandinavica.

29. Fakhruddin, K. S., Gorduysus, M. O., \& El Batawi, H. (2016). Effectiveness of behavioral modification techniques with visual distraction using intrasulcular local anesthesia in hearing disabled children during pulp therapy. European journal of dentistry, 10(04), 551-555.

30. Lopez, M. C., Deliens, G., \& Cleeremans, A. (2016). Ecological assessment of divided attention: what about the current tools and the relevancy of virtual reality. Revue neurologique, 172(4-5), 270280. 
31. Piskorz, J., \& Czub, M. (2018). Effectiveness of a virtual reality intervention to minimize pediatric stress and pain intensity during venipuncture. Journal for Specialists in Pediatric Nursing, 23(1), e12201.

32. Fakhruddin, K. S., El Batawi, H., \& Gorduysus, M. O. (2017). Effectiveness of audiovisual distraction with computerized delivery of anesthesia during the placement of stainless steel crowns in children with Down syndrome. European journal of dentistry, 11(01), 001-005.

33. Wang, Z., Whiteside, S., Sim, L., Farah, W., Morrow, A., Alsawas, M., ... \& Daraz, L. (2017). Anxiety in Children.

34. Gaffary, Y., Le Gouis, B., Marchal, M., Argelaguet, F., Arnaldi, B., \& Lécuyer, A. (2017). AR feels "softer" than VR: haptic perception of stiffness in augmented versus virtual reality. IEEE transactions on visualization and computer graphics, 23(11), 2372-2377.

35. Asl, A. N., Shokravi, M., Jamali, Z., \& Shirazi, S. (2017). Barriers and drawbacks of the assessment of dental fear, dental anxiety and dental phobia in children: A critical literature review. Journal of Clinical Pediatric Dentistry, 41(6), 399-423.

36. Fakhruddin, K. S., \& El Batawi, H. Y. (2017). Effectiveness of audiovisual distraction in behavior modification during dental caries assessment and sealant placement in children with autism spectrum disorder. Dental research journal, 14(3), 177.

37. Seligman, L. D., Hovey, J. D., Chacon, K., \& Ollendick, T. H. (2017). Dental anxiety: An understudied problem in youth. Clinical psychology review, 55, 25-40.

38. Cianetti, S., Paglia, L., Gatto, R., Montedori, A., \& Lupatelli, E. (2017). Evidence of pharmacological and non-pharmacological interventions for the management of dental fear in paediatric dentistry: a systematic review protocol. BMJ open, 7(8), e016043.

39. Keller, M. S., Park, H. J., Cunningham, M. E., Fouladian, J. E., Chen, M., \& Spiegel, B. M. R. (2017). Public perceptions regarding use of Virtual Reality in health care: a social media content analysis using Facebook. Journal of medical Internet research, 19(12), e419.

40. Humphris, G., Spyt, J., Herbison, A. G., \& Kelsey, T. W. (2016). Adult dental anxiety: Recent assessment approaches and psychological management in a dental practice setting. Dental update, 43(4), 388-394.

41. Glennon, C., McElroy, S. F., Connelly, L. M., Lawson, L. M., Bretches, A. M., Gard, A. R., \& Newcomer, L. R. (2018, July). Use of Virtual Reality to Distract From Pain and Anxiety. In Oncology nursing forum (Vol. 45, No. 4).

42. Brunetti, G. A., Tendas, A., Meloni, E., Mancini, D., Maggiore, P., Scaramucci, L., ... \& Alimena, G. (2011). Pain and anxiety associated with bone marrow aspiration and biopsy: a prospective study on 152 Italian patients with hematological malignancies. Annals of hematology, 90(10), 12331235 .

43. Cerichione, C., Picardi, M., Pugliese, N., Della Pepa, R., Gravetti, A., Casoria, A., \& Martinelli, V. (2017). Combined oral administration of analgesia and anxiolysis for pain associated with bone marrow aspiration and biopsy. Blood, 130(Supplement 1), 4715-4715.

44. Chirico, A., Lucidi, F., De Laurentiis, M., Milanese, C., Napoli, A., \& Giordano, A. (2016). Virtual reality in health system: beyond entertainment. a mini- review on the efficacy of VR during cancer treatment. Journal of cellular physiology, 231(2), 275-287.

45. Degen, C., Christen, S., Rovo, A., \& Gratwohl, A. (2010). Bone marrow examination: a prospective survey on factors associated with pain. Annals of hematology, 89(6), 619-624.

46. Gershon, J., Zimand, E., Lemos, R., Rothbaum, B. O., \& Hodges, L. (2003). Use of virtual reality as a distractor for painful procedures in a patient with pediatric cancer: a case study. CyberPsychology \& Behavior, 6(6), 657-661.

47. Grønkjær, M., Hasselgren, C. F., Østergaard, A. S. L., Johansen, P., Korup, J., Bøgsted, M., ... \& Jensen, P. (2016). Bone marrow aspiration: a randomized controlled trial assessing the quality of bone marrow specimens using slow and rapid aspiration techniques and evaluating pain intensity. Acta haematologica, 135(2), 81-87.

48. Harrington, S., Gilchrist, L., \& Sander, A. (2014). Breast cancer EDGE task force outcomes: clinical measures of pain. Rehabilitation oncology, 32(1), 13.

49. Hjortholm, N., Jaddini, E., Hałaburda, K., \& Snarski, E. (2013). Strategies of pain reduction during the bone marrow biopsy. Annals of hematology, 92(2), 145-149.

50. Hua, Y., Qiu, R., Yao, W. Y., Zhang, Q., \& Chen, X. L. (2015). The effect of virtual reality distraction on pain relief during dressing changes in children with chronic wounds on lower limbs. Pain Management Nursing, 16(5), 685-691.

51. Kindler, C. H., Harms, C., Amsler, F., Ihde-Scholl, T., \& Scheidegger, D. (2000). The visual analog scale allows effective measurement of preoperative anxiety and detection of patients' anesthetic concerns. Anesthesia \& Analgesia, 90(3), 706-712.

52. Kjeldsen, H. B., Klausen, T. W., \& Rosenberg, J. (2016). Preferred presentation of the visual analog scale for measurement of postoperative pain. Pain Practice, 16(8), 980-984.

53. Lechtzin, N., Busse, A. M., Smith, M. T., Grossman, S., Nesbit, S., \& Diette, G. B. (2010). A randomized trial of nature scenery and sounds versus urban scenery and sounds to reduce pain in adults undergoing bone marrow aspirate and biopsy. The Journal of Alternative and Complementary Medicine, 16(9), 965-972. 
54. Lidén, Y., Olofsson, N., Landgren, O., \& Johansson, E. (2012). Pain and anxiety during bone marrow aspiration/biopsy: comparison of ratings among patients versus health-care professionals. European Journal of Oncology Nursing, 16(3), 323-329.

55. Malloy, K. M., \& Milling, L. S. (2010). The effectiveness of virtual reality distraction for pain reduction: a systematic review. Clinical psychology review, 30(8), 1011-1018.

56. National Cancer Institute (n.d) NCI Dictionary of cancer terms. Hematologic cancer. Retrieved from https: // bit.ly/ 2 sylxot.

57. Nilsson, S., Finnström, B., Kokinsky, E., \& Enskär, K. (2009). The use of Virtual Reality for needlerelated procedural pain and distress in children and adolescents in a paediatric oncology unit. European Journal of Oncology Nursing, 13(2), 102-109.

58. Schneider, S. M., \& Hood, L. E. (2007, January). Virtual reality: a distraction intervention for chemotherapy. In Oncology nursing forum (Vol. 34, No. 1, p. 39). NIH Public Access.

59. Schneider, S. M., Prince-Paul, M., Allen, M. J., Silverman, P., \& Talaba, D. (2004, January). Virtual reality as a distraction intervention for women receiving chemotherapy. In Oncology nursing forum (Vol. 31, No. 1).

60. Shabanloei, R., Golchin, M., Esfahani, A., Dolatkhah, R., \& Rasoulian, M. (2010). Effects of music therapy on pain and anxiety in patients undergoing bone marrow biopsy and aspiration. AORN journal, 91(6), 746-751.

61. Tanasale, B., Kits, J., Kluin, P. M., Trip, A., \& Kluin-Nelemans, H. C. (2013). Pain and anxiety during bone marrow biopsy. Pain Management Nursing, 14(4), 310-317.

62. Tanja-Dijkstra, K., Pahl, S., White, M. P., Andrade, J., Qian, C., Bruce, M., \& Moles, D. R. (2014). Improving dental experiences by using virtual reality distraction: a simulation study. PLoS One, 9(3).

63. Tse, M. M., Ng, J. K., Chung, J. W., \& Wong, T. K. (2002). The effect of visual stimuli on pain threshold and tolerance. Journal of clinical nursing, 11(4), 462-469.

64. Wahn, B., \& König, P. (2017). Is attentional resource allocation across sensory modalities taskdependent?. Advances in Cognitive Psychology, 13(1), 83.

65. Walker, M. R., Kallingal, G. J., Musser, J. E., Folen, R., Stetz, M. C., \& Clark, J. Y. (2014).
Treatment efficacy of virtual reality distraction in the reduction of pain and anxiety during cystoscopy. Military medicine, 179(8), 891-896.

66. Wint, S. S., Eshelman, D., Steele, J., \& Guzzetta, C. E. (2002, January). Effects of distraction using virtual reality glasses during lumbar punctures in adolescents with cancer. In Oncology nursing forum (Vol. 29, No. 1).

67. Wolitzky, K., Fivush, R., Zimand, E., Hodges, L., \& Rothbaum, B. O. (2005). Effectiveness of virtual reality distraction during a painful medical procedure in pediatric oncology patients. Psychology and health, 20(6), 817-824

68. Zahid, M. F. (2015). Methods of reducing pain during bone marrow biopsy: a narrative review. Annals of palliative medicine, 4(4), 184.

69. Hoffman, H. G., Richards, T. L., Coda, B., Bills, A. R., Blough, D., Richards, A. L., \& Sharar, S. R. (2004). Modulation of thermal pain-related brain activity with virtual reality: evidence from fMRI. Neuroreport, 15(8), 1245-1248.

70. Hoffman, H. G., Sharar, S. R., Coda, B., Everett, J. J., Ciol, M., Richards, T., \& Patterson, D. R. (2004). Manipulating presence influences the magnitude of virtual reality analgesia. Pain, 111(12), 162-168.

71. Gold, J. I., Belmont, K. A., \& Thomas, D. A. (2007). The neurobiology of virtual reality pain attenuation. CyberPsychology \& Behavior, 10(4), 536-544.

72. Das, D. A., Grimmer, K. A., Sparnon, A. L., McRae, S. E., \& Thomas, B. H. (2005). The efficacy of playing a virtual reality game in modulating pain for children with acute burn injuries: a randomized controlled trial [ISRCTN87413556]. BMC pediatrics, 5(1), 1.

73. Hoffman, H. G., Patterson, D. R., \& Carrougher, G. J. (2000). Use of virtual reality for adjunctive treatment of adult burn pain during physical therapy: a controlled study. The Clinical journal of pain, 16(3), 244-250.

74. Mathew, P. J., \& Mathew, J. L. (2003). Assessment and management of pain in infants. Postgraduate Medical Journal, 79(934), 438-443.

75. Ram, D., \& Peretz, B. (2002). Administering local anaesthesia to paediatric dental patients-current status and prospects for the future. International journal of paediatric dentistry, 12(2), 80-89.

76. McCaul, K. D., \& Malott, J. M. (1984). Distraction and coping with pain. Psychological bulletin, 95(3), 516 . 